\title{
Weathering of basaltic glass dust in Icelandic wetlands as a natural analogue to enhanced rock weathering (ERW) and carbon solubility storage
}

\author{
TOBIAS LINKE ${ }^{1}$, SHIKHAR NILABH ${ }^{2}$, FIDEL GRANDIA ${ }^{2}$, \\ SUSANNE CLAUDIA MÖCKEL ${ }^{3}$, KNUD DIDERIKSEN $^{4,5}$ \\ AND SIGURDUR R GISLASON ${ }^{1}$ \\ ${ }^{1}$ Institute of Earth Sciences, University of Iceland \\ ${ }^{2}$ Amphos 21 \\ ${ }^{3}$ Institute of Life and Environmental Sciences, University of \\ Iceland \\ ${ }^{4}$ Geological Survey of Denmark \& Greenland (GEUS) \\ ${ }^{5}$ Nano-Science Center, University of Copenhagen \\ Presenting Author: tol5@hi.is
}

Peat areas in south central Iceland receive huge amounts (500$\left.800 \mathrm{gm}^{-2} \mathrm{yr}^{-1}\right)$ of fine-grained basaltic glass dust during storm events [1]. These dust particles are in the size range of 100 to 1 $\mu \mathrm{m}$ [1] yielding a high reactive surface area load, which is comparable to those suggested for enhanced rock weathering (ERW) field experiments [2].

We sampled soil solutions in a histic andosol soil that commonly consists of less than $20 \%$ organic matter and huge amounts of basaltic glass in south central Iceland. Suction cups and Rhizon samplers were inserted at 10-260 $\mathrm{cm}$ depth within the soil. The $\mathrm{pH}$ and alkalinity increased with depth while the solutions became more reduced. The $\mathrm{pH}$ ranged from 5.5-6.7. At the highest $\mathrm{pH}$, about half of the dissolved inorganic carbon was present as bicarbonate $\left(\mathrm{HCO}_{3}^{-}\right)$.

The $\mathrm{pH}$ is a direct result of the combination of two natural processes: (1) decomposition of organic matter and (2) weathering of basaltic glass. Fast dissolution rate of the basaltic glass is maintained by the formation of allophane $\left(\mathrm{Al}_{2} \mathrm{O}_{3} \mathrm{SiO}_{2}\right)$ $\left(\mathrm{H}_{2} \mathrm{O}\right)_{2.53}$, which keeps the $\mathrm{Al}^{3+}$ activity low in the entire soil body. In addition, iron precipitated under oxic and reduced conditions as ferrihydrite $\left(\mathrm{Fe}(\mathrm{OH})_{3}\right)$ or siderite $\left(\mathrm{FeCO}_{3}\right)$, respectively. Simultaneously, sulphur and heavy metal concentrations decreased with depth, where siderite and mackinawite (FeS) were close to saturation. According to reaction path modelling the mass of dissociation of organic carbon within the soil solutions was $4 \mathrm{mmol} / \mathrm{kg}$ while the basaltic glass dissolution was estimated to be $1.2 \mathrm{mmol} / \mathrm{kg}$.

These results indicate a higher $\mathrm{CO}_{2}$ solubility and mineral storage of the Icelandic peat soil studied here compared to other peat areas receiving only limited fine-grained air born basaltic glass dust.

[1] Arnalds, Dagsson-Waldhauserova \& Olafsson (2016), Aeolian Research 20, 176-195.

[2] Haque, Chiang \& Santos (2019), Energies 12, 1-17. 